\title{
Statistical analysis of morphometric indicators and physical readiness variability of students
}

\author{
Gainullin R.A. ${ }^{1}$, Isaev A.P. ${ }^{2}$, Zalyapin V.I. ${ }^{2}$, Korablyova Y.B. ${ }^{2}$ \\ ${ }^{1}$ Bashkir State Medical University, Russia \\ ${ }^{2}$ South Ural State University, Russia
}

\begin{abstract}
Purpose:

To evaluate the interaction of morphometric characteristics with the reactions of the cardiorespiratory system and the indices of physical training during the process of physical exercise training at the university.

Material: $\quad$ The students of the first course $(n=91$, aged $17-18)$ took part in the survey. The students were divided into 6 groups. All students were engaged in physical training. All the studied indicators were conditionally divided into two groups. The first group of studies included indicators of physical fitness. The second group was formed by morphofunctional indices.

Results: $\quad$ The indicators of the physical preparedness of students demonstrate a wide range and heterogeneity. This should be taken into account when staffing training groups. When using the technique of development of local regional muscular endurance, the values of orthostatic test and the Skibinski index show significant variability. Also high and significant correlation interactions are shown by indicators: manual dynamometry; strength endurance; the values of the Skibinski index. Also, in the orthotropic test, the same effect was observed: age, body length, heart rate. A similar analysis of morphofunctional indices shows significant correlation links: the Skibinski index and orthotropic tests; age and the Skibinski index; weight and body length.

Conclusions: from the point of view of physical fitness, groups of sports training (the second group) and hypertensive groups (group 5) proved to be the most stable. A group of volunteers turned out to be the most stable relative to the morphofunctional indicators.

Keywords: $\quad$ health indicators, motor activity, statistical analysis, variability, physical readiness.
\end{abstract}

\section{Introduction}

Education in higher education is a complex and lengthy process. A number of authors note a number of problems that develop into intellectual, emotional and mental stress. The main reason for this is as follow: the changed socio-economic conditions of students' study and life; excess strain. This phenomenon takes on stagnant nature and aggravated by a decrease of physical activity [8]. Adaptation of students takes place against the backdrop of intensified learning, the increasing volume of teaching load, the changing forms and methods of teaching, and pedagogical requirements. Such intensification is accompanied by an increased load on the psychophysiological potential (PPP) $[5,6]$. One of the modern and accessible methods for assessing the relationship between the work of the cardiorespiratory system is the assessment of physical preparedness and morphofunctional indices $[4,13]$. There is a sufficient amount of data to study the variability of the cardiorespiratory system at rest and in the transition to the orthostatic position $[10,22,26]$. The study of changes in various variability in the phenomena of the organism, which makes it possible to disclose the features of the functioning of the organism and systems, the regulation of physiological systems is of a great interest in physiology [2].

Morphometric indicators for the prospects of young athletes are presented in various studies $[1,3,9]$. However, there is no detailed analysis in physical education among students. Different contingent and methods do not allow such a comparison. It is needed more researches. We have not encountered similar structuring and differentiation of groups in the literature. Therefore, it is impossible to compare the obtained data.

(c) Gainullin R.A., Isaev A.P., Zalyapin V.I., Korablyova Y.B. , 2017 doi:10.15561/20755279.2017.0502
The main goal of physical education and mass sports at the university is as follows: to make students healthier; improving the level of motor activity; preparation for participation in local (intra-university, district and interuniversity) and regional (city, regional and republican) student competitions.

Morphometric features of a person are one of the genetically predetermined factors. They determine the specific physical development of the individual and allow us to assess reserve capabilities in motor activity and mass sports. Distribution of loads in different training groups depends on hereditary factors, features of the habitat and differentiation of structural indicators. It is necessary to take into account the peculiarities of biorhythms, reactivity, physiology of adaptation processes [5, 11, 12].

Other studies highlight the main directions for improving the system of physical education of students such as: program has been developed that will enable and effectively develop and maintain a level of health in physical education [21]; it has been established that personal, psychosocial and environmental factors are closely related to moderate and vigorous motor activity [23]; the level of teacher training influences the successful formation of the necessary competencies of students [14, 23]; satisfaction of the basic needs of students leads to greater self-determined motivation. This helps to increase cognitive skills and motor activity [20].

Important element of the physical education system is as follow: optimization of physical activities $[16,19]$; the use of modern means and methods of teaching $[15,25]$; accounting for individual morphofunctional indicators $[17,27]$; the organization of pedagogical control over motor readiness of students [18].

Such approaches allow to motivate students: to success through physical education classes; to a positive 
attitude towards one's health.

The aim of the study is to trace possible interactions of morphometric characteristics with reactions of the cardiorespiratory system and indicators of physical preparedness.

\section{Material and methods}

Participants. According to the medical examination and choice of sports, students were divided into 6 groups: disorders of the musculoskeletal system and cardiopulmonary system ( $\mathrm{n}=91$, age $17-18$ years). The characteristics of the groups by composition and formation characteristics are given in Table 1.

The following parameters were studied: age, weight and body length, levels of systolic (SAD) and diastolic (DAD) pressure, orthostatic test (ort), the Skibinski index (ind Skib), mixed stops ( $s \_u$ p), indicators of pulling and loading press (pod_press), indicators of manual dynamometry (right $-\mathrm{F}$ right and left $-\mathrm{F} \_$left). As indicators of physical readiness, the results of a cross between 500-1000 $\mathrm{m}$ (cross) and a sprint - running at 100 $\mathrm{m}$ (sprint) were considered.

Organization of the study. The first-year students engaged in physical training in one of the following training groups were examined: SMG (special medical group); with disorders in the cardiovascular system (CVS) - hypertensive; volunteers involved in general physical training; group with respiratory diseases; main group; sports group. Diagnosis was carried out using functional samples.

Each group was engaged in its programs. Sports groups were in training everyday two hours a day five times a week. The main group was engaged three times a week according to the program of physical education of universities [1]. Also this group attended classes in the chosen sport twice a week. A group of volunteers practiced twice a week. It also took part in weekend trips. Groups with a violation of the cardiorespiratory system were engaged in low intensity physical exercises of a special correction. Special medical group (SMG) was engaged three times a week by educational corrective and sparing loads. Also this group was engaged two days a week on individual plans. The methodology for the development of local-regional muscular endurance (LRME) was put in the basic framework for the preparation of students (groups 1, $2,4)$. Such a technique had an aerobic orientation [7].

Excess body weight can lead to an increased level of traumatism of students. Therefore, in the classes on physical training of students were included preventive, corrective-restorative and rehabilitation measures. A certain role was assigned to static stretching, swimming, the creation of an artificially training and restoring environment $[3,12]$.

All the studied indicators were conditionally divided into two groups. The first group included indicators of physical readiness: mixed stops $\left(s \_u \_p\right)$, indicators of pullup and load on the press (pod_press), indicators of manual dynamometry (right $-F_{\text {r right }}$ and left $-F_{-}$left), cross results on $500-1000 \mathrm{~m}$ (cross) and sprint on $100 \mathrm{~m}$ (sprint). Thus, the indices of the first group reflect the response of the subjects to force loads. These indicators describe the motor abilities of individuals (power endurance, manual dynamometry), general endurance (running at 1000 and $500 \mathrm{~m}$ ) and speed-power characteristics. The second group was formed by morphofunctional parameters: age, weight and body length, levels of systolic (SAD) and diastolic (DAD) pressure, orthostatic test (ort), the Skibinski index (ind_Skib).

Statistical analysis. To establish the significance of differences in physical fitness indicators in different training groups was used rank criteria of Kruskal-Wallis test. The mean and error of the mean, the strength of the correlation bonds, Pearson correlation coefficients were calculated.

\section{Results}

The general characteristics of the studied indicators are given in Table 2 (indicators of the first group) and Table 3 (indicators of the second group).

Table 1. Participants and groups of physical training

\begin{tabular}{llll}
\hline No of group & Code of group & Number of memberships & Peculiarities \\
\hline $\mathbf{1}$ & Main & 15 & Main, boxers \\
$\mathbf{2}$ & Sports & 15 & Sport, swimmers \\
$\mathbf{4}$ & SMG (MSS) & 15 & SMG, MSS \\
$\mathbf{5}$ & Volunteers & 15 & Volunteers - GPT \\
$\mathbf{6}$ & Hypertensive & 15 & CVS deviation \\
\hline
\end{tabular}

Note. SMG - special medical group, MSS - musculoskeletal system, GPT - general physical training, CVS - cardiovascular system. 
The age of the subjects is fairly homogeneous (1718 years). Indicators of length and body weight also do not change very much. Blood pressure values are in the reference range for this age group.

The values of the orthotropic test and the Skibinski index show significant variability within the studied population.

Correlation effects. The analysis of correlation links between the indices of students' physical readiness (Table 4 - Pearson correlation coefficients, second line - significance levels) did not show significant mutual influences: in cross and sprint; these indicators with other indicators of physical fitness. Weak (but significant!) correlation relationships demonstrate the pull-up + press with variable mixed supports and with indicators of manual dynamometry. High and significant correlation interactions show the indicators of manual dynamometry.

A similar analysis of morphofunctional indices (Table 5) shows significant correlation links: the Skibinski index and orthostatic tests; age and the Skibinski index; physiologically obvious relationship between the weight and body length of the subjects.

Comparison of interrelations on the internal-system (morphofunctional) and inter-system level with the results of cross and sprint should note the following. Among modern students system regulation and interrelation is carried out against the background of prolonged stresstension, present in all groups of subjects. These processes occur in different ways. Clearly identified groups with greater synchronization and less dysregulation of the function. This is evidenced by the mechanisms of adaptation and dysregulation in the examined groups. From the information material on the state and preparedness can be found information about: which groups of students are more adapted to information loads; what groups are in the ranges of physiological stress; which are in a premorbid and stressful state $[7,12]$.

It should be noted that the observed relationships (Table 4,5 ) between the indicators allow us to judge their role in the integrative activity of the organism. Strength endurance, strength of the hands and indicators of the cardiopulmonary system play a leading role in students life.

Intrasystem and intersystem connections allow us to talk about the inefficient adaptation of students to the significant loads associated with the educational process. In this connection, it became necessary to conduct a structural analysis of the studied indicators, which will

Table 2. Statistics of the first group indicators

\begin{tabular}{llllll}
\hline Indicators & Number & Minimum & Maximum & Mean & Standard deviation \\
\hline Cross 500, $1000 \mathrm{~m}$ & 91 & 3,16 & 15,20 & 4,1520 & 1,71384 \\
Running $100 \mathrm{~m}$ & 91 & 12,50 & 18,92 & 14,5616 & 1,51757 \\
Six mixed supports & 91 & 1,56 & 16,00 & 11,8451 & 1,95370 \\
Pull-up, press & 91 & 9 & 75 & 52,98 & 13,578 \\
Strength of right hand & 91 & 20 & 85 & 41,60 & 9,430 \\
Strength of left hand & 91 & 18 & 70 & 37,52 & 8,160 \\
N of valid & 91 & & & & \\
\hline
\end{tabular}

Table 3. Statistics of the second group of indicators

\begin{tabular}{lllll}
\hline Indicators & Minimum & Maximum & Mean & Standard deviation \\
\hline Age & 17 & 32 & 18,78 & 1,705 \\
Body weight, kg & 40,5 & 100,0 & 68,312 & 9,6266 \\
Body length, cm & 153 & 198 & 175,09 & 7,850 \\
SAD, mm Hg & 110 & 175 & 131,68 & 12,972 \\
DAD, mm Hg & 50 & 91 & 74,67 & 8,266 \\
Orthostatic test & 2 & 50 & 11,42 & 7,152 \\
The Skibinski index, y.e. & 16,00 & 68,00 & 40,5940 & 14,38004 \\
\hline
\end{tabular}

Note: SBD - systolic blood pressure; DAD - diastolic blood pressure. 
Table 4. Pearson correlations. Physical fitness

\begin{tabular}{|c|c|c|c|c|c|c|}
\hline Indicators & $\begin{array}{l}\text { Cross 500, } \\
1000 \mathrm{~m}\end{array}$ & Sprint $100 \mathrm{~m}$ & $\begin{array}{l}\text { Six mixed } \\
\text { supports }\end{array}$ & Pull-up, press & $\begin{array}{l}\text { Strength of } \\
\text { right hand }\end{array}$ & $\begin{array}{l}\text { Strength of } \\
\text { left hand }\end{array}$ \\
\hline \multirow{2}{*}{$\begin{array}{l}\text { Cross 500, } \\
1000 \mathrm{~m}\end{array}$} & 1 & ,090 &,- 083 & ,042 & ,022 & ,061 \\
\hline & & ,396 & ,432 & 693 & ,833 & ,568 \\
\hline \multirow{2}{*}{$100 \mathrm{~m}$} & ,090 & 1 &,- 077 &,- 004 &,- 030 &,- 112 \\
\hline & ,396 & & ,470 & 970 & ,777 & 292 \\
\hline \multirow{2}{*}{$\begin{array}{l}\text { Six mixed } \\
\text { supports }\end{array}$} &,- 083 &,- 077 & 1 &,$- 377^{* *}$ &,$- 268 *$ &,- 191 \\
\hline & ,432 & ,470 & & ,000 & ,010 & ,070 \\
\hline \multirow{2}{*}{ Pull-up, press } & ,042 &,- 004 &,$- 377 * *$ & 1 &, $278 * *$ &, $331 * *$ \\
\hline & ,693 & ,970 & ,000 & & ,008 & ,001 \\
\hline \multirow{2}{*}{$\begin{array}{l}\text { Strength of } \\
\text { right hand }\end{array}$} & ,022 &,- 030 &,$- 268 *$ &, $278 * *$ & 1 &, $905^{* *}$ \\
\hline & ,833 & ,777 & ,010 & ,008 & & ,000 \\
\hline \multirow{2}{*}{$\begin{array}{l}\text { Strength of } \\
\text { left hand }\end{array}$} & ,061 &,- 112 & -191 & ,331** &, $905^{* *}$ & 1 \\
\hline &, 568 & ,292 & ,070 & ,001 & ,000 & \\
\hline
\end{tabular}

Table 5. Pearson correlations. Morphofunctional indicators

\begin{tabular}{|c|c|c|c|c|c|c|c|}
\hline Indicators & Age & $\begin{array}{l}\text { Body } \\
\text { weight, kg }\end{array}$ & $\begin{array}{l}\text { Body } \\
\text { length, } \\
\mathrm{cm}\end{array}$ & SAD & DAD & $\begin{array}{l}\text { Orthostatic } \\
\text { test }\end{array}$ & $\begin{array}{l}\text { The Skibinski } \\
\text { index }\end{array}$ \\
\hline \multirow{2}{*}{ Age } & 1 &,- 002 & ,062 &,- 057 & ,062 &,- 088 & $280^{* *}$ \\
\hline & & 983 & ,558 & ,592 & ,561 & ,406 & ,007 \\
\hline \multirow{2}{*}{ Body weight, kg } &,- 002 & 1 &, $633^{* *}$ & ,099 &,- 067 &,- 186 & ,084 \\
\hline & ,983 & & ,000 & ,352 & ,525 & 077 & ,428 \\
\hline \multirow{2}{*}{ Body length, cm } & ,062 &, $633^{* *}$ & 1 &,- 035 &,- 073 &,- 166 & ,034 \\
\hline & ,558 & ,000 & & ,742 & ,489 & 115 & 751 \\
\hline \multirow{2}{*}{$\mathrm{SAD}, \mathrm{mm} \mathrm{Hg}$} &,- 057 & ,099 &,- 035 & 1 &,- 013 & 172 & ,034 \\
\hline & ,592 & ,352 & ,742 & & ,906 & 104 & ,752 \\
\hline \multirow{2}{*}{ DAD, $\mathrm{mm} \mathrm{Hg}$} & ,062 &,- 067 &,- 073 &,- 013 & 1 &,- 034 &,- 101 \\
\hline & ,561 & ,525 & ,489 & 906 & & 747 & 339 \\
\hline \multirow{2}{*}{$\begin{array}{l}\text { Orthostatic test, alteration } \\
\text { of heart rate }\end{array}$} &,- 088 &,- 186 &,- 166 & 172 &,- 034 & 1 &,$- 278^{* *}$ \\
\hline & ,406 & ,077 & 115 & 104 & ,747 & & ,008 \\
\hline \multirow{2}{*}{ The Skibinski index, y.e. } & $280^{* *}$ & ,084 & ,034 & 034 &,- 101 &,$- 278^{* *}$ & 1 \\
\hline & ,007 & ,428 & ,751 & ,752 & ,339 &, 008 & \\
\hline
\end{tabular}

Note: SAD - systolic blood pressure, DAD - diastolic blood pressure.

allow to judge the heterogeneity (homogeneity) of the groups under study.

The aim of the analysis is to free from random (including erroneous) emissions that are uncharacteristic for the population. As an example, consider the variable - age of students.

The range of this change and its frequency characteristics are shown in Table 6.

It can be seen from the table that the majority of students (85 out of 91 , that is, more than 93\%) are between the ages of 17 and 19. If we expand this range to 22 years, then it will get already almost $99 \%$ (90 out of 91) observations.

Therefore, the characteristic values of the variable age should be considered values from the specified range.

The age characteristics of the training groups turned out to be heterogeneous. The median Kruskal-Wallace test indicates a significant difference in age groups in different groups. Age students are in the first group.
Behind this group follows the fourth. Then the second and third indistinguishable by age are located. The youngest are members of the fifth and sixth groups.

Analogous arguments for other morphofunctional variables yield the results presented in Table 7 .

Comparison of the data in Table 7 with the initial data (Table 3) shows the following: the mean values of the indicators and the coverage of the observations have changed insignificantly; is saved from $94 \%$ to $98 \%$ of the original experimental data. At the same time, the initial range of variation of the orthotropic variable has changed significantly - it has almost halved.

Distribution of indicators by group. The distribution of the average values of the studied indicators by training groups is presented in Table 8 and Table 9.

The greatest variation in the results was observed: in the cross - in the second group; in the $100 \mathrm{~m}$ race in the first and fourth groups; in terms of the indicator, mixed stops - in 3, 4, 6 groups; on the indicator pull-up + press - 
Table 6. Frequency characteristic of age

\begin{tabular}{lllll}
\hline $\begin{array}{l}\text { Lower bound of } \\
\text { indices }\end{array}$ & $\begin{array}{l}\text { Upper bound of } \\
\text { indices }\end{array}$ & $\begin{array}{l}\text { Mean } \\
\text { error }\end{array}$ & Number of observations & Relative frequency \\
\hline 16,0 & 18,3 & 17,1 & 44 & 0,4835 \\
18,3 & 20,5 & 21,6 & 5 & 0,4505 \\
20,5 & 22,8 & 23,9 & 0 & 0,0549 \\
22,8 & 25,0 & 26,1 & 0 & 0,0000 \\
25,0 & 27,3 & 28,4 & 0 & 0,0000 \\
27,3 & 29,5 & 30,6 & 0 & 0,0000 \\
29,5 & 31,8 & 32,9 & 1 & 0,0000 \\
31,8 & 34,0 & 21,6 & 0,0110 \\
\hline
\end{tabular}

Table 7. Typical (95\%) ranges of indicators change

\begin{tabular}{llll} 
Indicators & Diapason & Mean & Variation coefficient \\
\hline Body weight $(\mathrm{kg})$ & $49-93$ & 68.2 & 11.6 \\
Body length $(\mathrm{cm})$ & $162-189$ & 175 & 3.8 \\
SAD, mm Hg & $110-165$ & 131 & 8.9 \\
DAD, mm Hg & $52-87$ & 74.9 & 9.6 \\
Orthostatic test, heart rate & $2-22$ & 10.4 & 50.9 \\
The Skibinski test, y.e. & $18.2-65$ & 40.5 & 33.6 \\
\hline
\end{tabular}

in $6,4,1,5$ groups; on indicators of manual dynamometry with the right hand - in 1, 3, 4, 6 groups and the left hand - in 3, 1, 2, 6 groups.

The second group was the most homogeneous, followed by the fifth group. In the remaining groups, the variability of the indicators was more extensive.

To establish the significance of differences in physical fitness indicators in different training groups (Table 8), the rank criteria of Kruskal-Wallis test was used.

In the cross, the differences between the results shown by the participants of the second (the worst result) and the fourth (the best result) groups were statistically significant. Sprint results are as follows: outsiders (the third group) have indicators that are significantly different from the results of the leaders (4, 5 and 6 of the group). Groups one and two showed intermediate results. These groups are significantly different from groups 3,5 . The remaining differences are insignificant. Indicators of manual dynamometry in the first group significantly exceed similar indicators in other groups. In terms of pull-up + press: the first, second and fourth groups significantly exceed the fifth and sixth groups. According to the indicator mixed supports: the fifth and sixth groups outstrip the first two. The remaining groups occupy an intermediate position.

The differentiation of morphofunctional indices is presented in Table. 9. The greatest fluctuations were observed: the Skibinski index - in group 5, 2, 1; orthostyrene - in group 3; DAD - in the group 2, 3, 5; $\mathrm{SAD}$ - in group 1, 5; length of body - in group 3, 4, 5; body weight - in the group 1, 2, 6, 4, 3; age - in the group of 5,1 . On the length of the body a significant difference is observed between the third and the remaining groups. In the third group, the subjects are on average lower than in the other groups. The level of diastolic pressure is the same in all groups. By the level of systolic pressure: the first, second, fourth, fifth, sixth groups have the same, statistically indistinguishable SAD.

According to $S A D$ : the first and fifth groups differ significantly from the second and fourth groups. orthostatic test changes: from high rates in the third group to low - in the fourth. In this case, the first and second groups are not different from each other $(p<0.05)$. The Skibinski index shows a monotonous decrease from the 
first to the sixth group.

In mass sports, physical exertion is applied, which exposes the student to increased demands. Criteria for the morphofunctional capabilities of students, control standards and standards for normal and optimal health have been developed $[1,3]$.

A departure from normative assessments requires a deep structural and functional analysis and dynamic diagnosis of individual reference values of the key criteria of preparedness, functional status and health.

\section{Discussion.}

The indicators of SAD in sports and a group of volunteers were in the reference range. Indicators of

Table 8. Distribution of indicators of physical readiness

\begin{tabular}{|c|c|c|c|c|c|c|c|}
\hline Group & & $\begin{array}{l}\text { Cross } \\
500,1000, \mathrm{~m}\end{array}$ & $\begin{array}{l}\text { Sprint } \\
100 \mathrm{~m}\end{array}$ & $\begin{array}{l}\text { Six mixed } \\
\text { supports }\end{array}$ & $\begin{array}{l}\text { Pull-up } \\
\text { press }\end{array}$ & $\begin{array}{l}\text { Strength of } \\
\text { right hand }\end{array}$ & $\begin{array}{l}\text { Strength of left } \\
\text { hand } n\end{array}$ \\
\hline & Mean & 3,8427 & 14,4813 & 10,4287 & 61,93 & 50,80 & 46,13 \\
\hline \multirow[t]{3}{*}{1} & Minimum & 3,37 & 13,51 & 10,00 & 48 & 36 & 37 \\
\hline & Maximum & 5,30 & 18,70 & 11,30 & 75 & 85 & 70 \\
\hline & Mean & 5,4633 & 14,4400 & 10,5400 & 64,33 & 41,07 & 37,60 \\
\hline \multirow[t]{3}{*}{2} & Minimum & 3,32 & 12,70 & 9,02 & 55 & 36 & 32 \\
\hline & Maximum & 15,20 & 15,20 & 12,00 & 73 & 54 & 45 \\
\hline & Mean & 4,3313 & 17,4020 & 11,8847 & 50,13 & 35,07 & 30,80 \\
\hline \multirow[t]{3}{*}{3} & Minimum & 4,13 & 16,01 & 1,56 & 34 & 20 & 18 \\
\hline & Maximum & 4,60 & 18,92 & 16,00 & 62 & 62 & 52 \\
\hline & Mean & 3,5873 & 13,6833 & 12,0733 & 61,53 & 46,27 & 41,13 \\
\hline \multirow[t]{3}{*}{4} & Minimum & 3,16 & 13,03 & 10,10 & 40 & 37 & 32 \\
\hline & Maximum & 4,48 & 14,37 & 15,00 & 71 & 59 & 49 \\
\hline & Mean & 3,8320 & 13,5767 & 13,8667 & 45,75 & 37,13 & 33,60 \\
\hline \multirow[t]{3}{*}{5} & Minimum & 3,37 & 12,50 & 13,00 & 34 & 34 & 30 \\
\hline & Maximum & 4,53 & 15,00 & 15,00 & 58 & 39 & 38 \\
\hline & Mean & 3,8738 & 13,8350 & 12,2500 & 35,38 & 39,44 & 35,94 \\
\hline \multirow[t]{2}{*}{6} & Minimum & 3,32 & 13,04 & 9,90 & 9 & 24 & 18 \\
\hline & Maximum & 5,29 & 14,09 & 14,00 & 53 & 45 & 43 \\
\hline \multirow[t]{3}{*}{ Total } & Mean & 4,1520 & 14,5616 & 11,8451 & 52,98 & 41,60 & 37,52 \\
\hline & Minimum & 3,16 & 12,50 & 1,56 & 9 & 20 & 18 \\
\hline & Maximum & 15,20 & 18,92 & 16,00 & 75 & 85 & 70 \\
\hline
\end{tabular}

Table 9. Distribution of morphofunctional indicators

\begin{tabular}{|c|c|c|c|c|c|c|c|c|}
\hline Group & & Age & $\begin{array}{l}\text { Body } \\
\text { weight, kg }\end{array}$ & $\begin{array}{l}\text { Body } \\
\text { length, cm }\end{array}$ & $\begin{array}{l}\text { SAD, } \\
\text { mm Hg }\end{array}$ & $\begin{array}{l}\text { DAD, } \\
\text { mm Hg }\end{array}$ & $\begin{array}{l}\text { Orthostatic } \\
\text { test, heart } \\
\text { rate }\end{array}$ & $\begin{array}{l}\text { The Skibinski } \\
\text { index, } \\
\text { y.e. }\end{array}$ \\
\hline & Mean & 20,00 & 70,467 & 175,47 & 139,73 & 73,60 & 8,40 & 61,4333 \\
\hline \multirow[t]{3}{*}{1} & Minimum & 19 & 56,0 & 167 & 116 & 57 & 2 & 45,00 \\
\hline & Maximum & 22 & 100,0 & 186 & 167 & 87 & 11 & 68,00 \\
\hline & Mean & 18,47 & 71,827 & 176,87 & 123,20 & 73,40 & 7,00 & 51,6667 \\
\hline \multirow[t]{3}{*}{2} & Minimum & 18 & 58,4 & 165 & 112 & 52 & 7 & 38,00 \\
\hline & Maximum & 19 & 95,0 & 198 & 138 & 88 & 7 & 62,00 \\
\hline & Mean & 18,47 & 63,300 & 169,13 & 132,53 & 73,60 & 22,13 & 36,6800 \\
\hline \multirow[t]{3}{*}{3} & Minimum & 18 & 40,5 & 153 & 126 & 56 & 14 & 26,20 \\
\hline & Maximum & 19 & 80,0 & 192 & 142 & 91 & 50 & 53,00 \\
\hline & Mean & 19,00 & 68,533 & 176,57 & 125,00 & 76,13 & 4,67 & 40,0240 \\
\hline \multirow[t]{3}{*}{4} & Minimum & 19 & 46,0 & 170 & 115 & 68 & 2 & 33,00 \\
\hline & Maximum & 19 & 76,0 & 185 & 135 & 85 & 8 & 49,30 \\
\hline & Mean & 18,87 & 69,830 & 177,93 & 140,47 & 72,07 & 15,60 & 32,7800 \\
\hline \multirow[t]{3}{*}{5} & Minimum & 17 & 58,0 & 165 & 120 & 50 & 8 & 23,00 \\
\hline & Maximum & 32 & 84,0 & 189 & 165 & 85 & 20 & 58,00 \\
\hline & Mean & 17,94 & 66,063 & 174,63 & 129,31 & 78,94 & 10,75 & 22,2056 \\
\hline \multirow[t]{2}{*}{6} & Minimum & 17 & 49,0 & 169 & 110 & 74 & 6 & 16,00 \\
\hline & Maximum & 18 & 81,0 & 187 & 175 & 85 & 17 & 29,00 \\
\hline \multirow[t]{3}{*}{ Total } & Mean & 18,78 & 68,312 & 175,09 & 131,68 & 74,67 & 11,42 & 40,5940 \\
\hline & Minimum & 17 & 40,5 & 153 & 110 & 50 & 2 & 16,00 \\
\hline & Maximum & 32 & 100,0 & 198 & 175 & 91 & 50 & 68,00 \\
\hline
\end{tabular}


SAD in the group with respiratory disorders were in the borderline. In the remaining groups, SAD values exceeded the norm limits. These data confirm the existing thesis that even the representatives of the main group were in tension (especially with hypertensive disorders). Similar differences in groups in the literature, we have not met. Therefore, when comparing, they were guided by normative indicators. In this regard, in the group with hypertensive disorders, the Skibinski index was lower. In the process of work, this group was subjected to a corrective effect and a tendency to improve indicators was revealed.

Group 2 consisted of students with good physical training or having 3 ranks. The total characteristics of students and athletes did not differ significantly. Differences were detected in the values of blood pressure, which in students exceeded those of athletes. In athletes of cyclic sports (starting from the initial stage of selection), these indicators looked preferable under conditions of relative quiescence and under orthotropic conditions [9]. Especially clearly these differences were manifested when comparing athletes of high qualification [12]. It can be assumed that, due to heavy loads in sport of high achievements, the heart works more economically. In this case, peripheral vessels are subject to relaxation, which reduces their resistance and diastolic pressure.

The spread of indicators of total body size depends on the variability, age, health status, and violations. The values of SAD exceeding the reference boundaries ( 5 , $1,3,6$ of the group) were observed. The maximal DAD indices indicated the peripheral vascular tension of the central hemodynamics (orthostatic test group 3).

\section{References}

1. Abramova TF, Nikitina TM, Kochetkova NI. Morphofunctional criteria-indices of adaptability of general physical training and control of current and long-term adaptation to training. Moscow: Division; 2010. (in Russian)

2. Baevskij RM. Prediction of conditions on the verge of norm and pathology. Moscow: Medicine; 1979. (in Russian)

3. Bulich EG, Muravov IV. Human health: Biological basis of vital activity and motor activity in its stimulation. Kiev: Olympic Literature; 2003. (in Russian)

4. Brekhman II. Valeology: diagnostics, means and practice of providing health. Vladivostok: Dalnauka; 1995. (in Russian)

5. Gainullin R, Isaev A, Erlikh V, Korablyova Y. External respiration system depending on the previous place of living in Bashkir State Medical University (BSMU) students from different countries. Human. Sport. Medicine. 2017;17(1):1427.

6. Gattarov RU. Psychophysiological potential and level of students' health. Chelyabinsk: SUSU; 2005. (in Russian)

7. Isaev A, Erlikh V, Ezhov VB. Local and regional muscular endurance in the system of preparation and adaptation of runners and skiers-riders in the conditions of the plain and middle mountains. Chelyabinsk: SUSU; 2014. (in Russian)

8. Isaev AP, Bykov EV, Khodas VV, Mkrtumian AM, Koroleva IuG. Fundamentals of health building of students. Chelyabinsk: SUSU; 2002. (in Russian)

9. Sirotin OA, Baturin NA. Systematization of sports selection criteria. Chelyabinsk: CGIFK; 1991. (in Russian)

10.Sabir'ianov AR. Some features of the variability of the central

\section{Conclusions}

1. In the studied population, the morphometric parameters are stable (body length, SAD, DAD, body weight,). The Skibinski index and heart rate (orthostatic test) demonstrate significant variability. This characterizes the individual manifestation of the parameters.

2. Results in cross and sprint shows no significant impact on them of other indicators of physical fitness of students.

3. Analysis of correlation links revealed ineffective adaptation and mechanisms of dysregulation of students' functions in the conditions of the educational process.

4. In the system of connections between the indicators of physical readiness, the values of manual dynamometry and strength endurance dominated. Among the parameters of the functional state, the values of the Skibinski index dominated. The same influence was shown: age, body length and heart rate in orthostatic test.

5. The groups of sports training (the second group) and hypertensive (group 5) proved to be the most stable in terms of physical fitness. The most stable relative to the morphofunctional indicators was a group of volunteers (group 4).

\section{Acknowledgement}

The article was supported by the Government of the Russian Federation (Resolution No. 211 from March 16, 2013), agreement No. 02.A03.21.0011.

\section{Conflict of interest}

The authors state that there is no conflict of interest.

circulation at rest and in the transition to the orthostatic position. Obrazovanie, zdravookhranenie, fizkul'tura i sport, 2003; 5(6): 95-98. (in Russian)

11. Sologub EB, Tajmazov VA. Sports genetics. Moscow: TerraSport; 2000. (in Russian)

12.Erlikh VV. Integral reactivity of runners organism in conditions of application of technologies for improving sports performance. Chelyabinsk; 2015. (in Russian)

13.Barbosa J, Basso L, Seabra A, Prista A, Tani G, Maia JAR, et al. Relationship between physical activity, physical fitness and multiple metabolic risk in youths from Muzambinho's study. European Journal of Sport Science. 2016;16(5):61823 .

14.Hall TJ, Hicklin LK, French KE. Teacher Compliance and Accuracy in State Assessment of Student Motor Skill Performance. Journal of Teaching in Physical Education. 2015;34(4):588-602.

15.Hastie PA, Ward JK, Brock SJ. Effect of graded competition on student opportunities for participation and success rates during a season of Sport Education. Physical Education and Sport Pedagogy. 2017;22(3):316-27.

16.Iermakov SS, Arziutov GN, Jagiello W. Quick training of students to judo techniques. Archives of Budo. 2016;12:1524.

17.Iermakov SS, Podrigalo LV, Jagiello W. Hand-grip strength as an indicator for predicting the success in martial arts athletes. Archives of Budo. 2016;12:179-86.

18. Khudolii OM, Ivashchenko OV, Iermakov SS, Rumba OG. Computer simulation of Junior gymnasts' training process. 
Science of Gymnastics Journal, 2016;8(3):215-228.

19.Kriventsova I, Iermakov S, Bartik P, Nosko M, Cynarski W. (2017). Optimization of students-fencers' tactical training. Ido Movement for Culture-Journal of Martial Arts Anthropology, 17(3), 21-30. doi:10.14589/ido.17.3.3

20.Legrain P, Gillet N, Gernigon C, Lafreniere MA. Integration of Information and Communication Technology and Pupils' Motivation in a Physical Education Setting. Journal of Teaching in Physical Education. 2015;34(3):384-401.

21.Mayorga-Vega D, Montoro-Escano J, Merino-Marban R, Viciana J. Effects of a physical education-based programme on health-related physical fitness and its maintenance in high school students: A cluster-randomized controlled trial. European Physical Education Review. 2016;22(2):243-59.

22. Miyamoto T, Kamada H, Tamaki A, Moritani T. Lowintensity electrical muscle stimulation induces significant increases in muscle strength and cardiorespiratory fitness. European Journal of Sport Science. 2016;16(8):1104-10.

23.Molina P, Martinez-Baena A, Villamon M. Physical
Education Pedagogy: an analysis of research published in Spanish journals (2005-2014). Physical Education and Sport Pedagogy. 2017;22(4):378-89.

24.Molina-Garcia J, Queralt A, Estevan I, Sallis JF. Ecological correlates of Spanish adolescents' physical activity during physical education classes. European Physical Education Review. 2016;22(4):479-89.

25.Osipov AY, Kudryavtsev MD, Iermakov SS, Jagiello W. Topics of doctoral and postdoctoral dissertations devoted to judo in period 2000-2016 - the overall analysis of works of Russian experts Archives of Budo, 2017; 13: 1-10

26. Ozemek C, Whaley MH, Finch WH, Kaminsky LA. Maximal heart rate declines linearly with age independent of cardiorespiratory fitness levels. European Journal of Sport Science. 2017;17(5):563-70.

27.Podrigalo LV, Iermakov SS, Jagiełło W. Special indices of body composition as a criterion of somatic development of martial arts practitioners. Arch Budo Sci Martial Art Extreme Sport, 2017; 13: 5-12

\section{Information about the authors:}

Gainullin R.A.; http://orcid.org/0000-0002-5441-7480; nullin@mail.ru; Bashkir State Medical University; Lenin St., 3, Ufa, 450000, Russia.

Isaev A.P.; http://orcid.org/0000-0003-2640-0240; isaevap@susu.ru; South Ural State University; 76, Lenin prospekt, Chelyabinsk, Russia, 454080, Russia.

Zalyapin V.I.; http://orcid.org/0000-0001-6981-6305; nullin@mail.ru; South Ural State University; 76, Lenin prospekt, Chelyabinsk, Russia, 454080, Russia.

Korablyova Y.B.; http://orcid.org/0000-0002-4152-712X; julyaa-74@yandex.ru; South Ural State University; 76, Lenin prospekt, Chelyabinsk, Russia, 454080, Russia.

Cite this article as: Gainullin RA, Isaev AP, Zalyapin VI, Korablyova YB. Statistical analysis of morphometric indicators and physical readiness variability of students. Physical education of students, 2017;21(5):205-212. doi:10.15561/20755279.2017.0502

The electronic version of this article is the complete one and can be found online at: http://www.sportedu.org.ua/index.php/PES/issue/archive

This is an Open Access article distributed under the terms of the Creative Commons Attribution License, which permits unrestricted use, distribution, and reproduction in any medium, provided the original work is properly cited (http://creativecommons.org/licenses/by/4.0/deed.en)

Received: 08.08.2017

Accepted: 29.08.2017; Published: 09.09.2017 